\title{
Arab Women in Algeria
}

Hubertine Auclert lived in Algeria from 1888 to 1892. She had been a well known militant for women's political rights in France from the mid-1870's. She founded the women's suffrage movement and the first suffragist newspaper, La Citoyenne.

Les Femmes arabes en Algérie was published in 1900 in Paris by the Société d'éditions littéraires which no longer exists; it is my source for the following translation. Auclert's book is a collection of fragments from different sources - essays, articles sent to $L a$ Citoyenne, petitions, correspondence - juxtaposed without any thematic grouping. So, for the sake of clarity, without changing a single word nor the order of the text, I have divided it in seven thematic chapters (and gave them titles), keeping all of Auclert's intertitles but a few redundant ones, and changing the location of one of them. I have added footnotes and a glossary of Arabic and French terms. 